\title{
Review \\ Overview of the Development and Use of Akt Inhibitors in Prostate Cancer
}

\author{
Anis Gasmi 1,*D, Guilhem Roubaud ${ }^{2}$, Charles Dariane ${ }^{3} \mathbb{D}$, Eric Barret ${ }^{4}$, Jean-Baptiste Beauval ${ }^{5}$, \\ Laurent Brureau $^{6}$, Gilles Créhange ${ }^{7}$, Gaëlle Fiard ${ }^{8}\left(\mathbb{D}\right.$, Gaëlle Fromont ${ }^{9}$, Mathieu Gauthé ${ }^{10} \mathbb{D}$, Alain Ruffion ${ }^{11,12} \mathbb{D}$, \\ Raphaële Renard-Penna ${ }^{13}$, Paul Sargos ${ }^{14}$, Morgan Rouprêt ${ }^{15}$, Guillaume Ploussard ${ }^{5}$ and Romain Mathieu ${ }^{1,16}$
}

check for

updates

Citation: Gasmi, A.; Roubaud, G.;

Dariane, C.; Barret, E.; Beauval, J.-B.; Brureau, L.; Créhange, G.; Fiard, G.;

Fromont, G.; Gauthé, M.; et al.

Overview of the Development

and Use of Akt Inhibitors in

Prostate Cancer. J. Clin. Med. 2022, 11

160. https://doi.org/10.3390/

jcm11010160

Academic Editor: Petros Grivas

Received: 4 December 2021

Accepted: 24 December 2021

Published: 29 December 2021

Publisher's Note: MDPI stays neutral with regard to jurisdictional claims in published maps and institutional affiliations.

Copyright: (C) 2021 by the authors. Licensee MDPI, Basel, Switzerland. This article is an open access article distributed under the terms and conditions of the Creative Commons Attribution (CC BY) license (https:// creativecommons.org/licenses/by/ $4.0 /)$.
1 Department of Urology, University of Rennes, 35000 Rennes, France; Romain.MATHIEU@chu-rennes.fr

2 Department of Medical Oncology, Institut Bergonié, 33000 Bordeaux, France;

G.Roubaud@bordeaux.unicancer.fr

3 Department of Urology, Hôpital Européen Georges-Pompidou, AP-HP, Paris University, 75005 Paris, France dcharlie8@hotmail.com

4 Department of Urology, Institut Mutualiste Montsouris, 75005 Paris, France; Eric.Barret@imm.fr

5 Department of Urology, La Croix du Sud Hôpital, Quint Fonsegrives, 31000 Toulouse, France; jbbeauval@gmail.com (J.-B.B.); g.ploussard@gmail.com (G.P.)

6 Department of Urology, CHU de Pointe-à-Pitre, University of Antilles, 97110 Pointe-à-Pitre, France; laurent.brureau@chu-guadeloupe.fr

7 Department of Urology, University Hospital, Université Grenoble Alpes, 38000 Grenoble, France; gilles.crehange@curie.fr

8 Department of Radiation Oncology, Curie Institute, 75005 Paris, France; gaellef@gmail.com

9 Department of Pathology, CHRU Tours, 37000 Tours, France; gaelle.fromont-hankard@univ-tours.fr

10 Department of Nuclear Medicine, Scintep, 38000 Grenoble, France; mathieugauthe@yahoo.fr

11 Service d'Urologie Centre Hospitalier Lyon Sud, Hospices Civils de Lyon, 69000 Lyon, France; ruffion.alain@orange.fr

12 Equipe 2, Centre d'Innovation en Cancérologie de Lyon (EA 3738 CICLY), Faculté de Médecine Lyon Sud, Université Lyon 1, 69000 Lyon, France

13 Department of Radiology, Sorbonne University, AP-HP, Pitie-Salpetriere Hospital, 75013 Paris, France; raphaele.renardpenna@gmail.com

14 Department of Radiotherapy, Institut Bergonié, 33000 Bordeaux, France; P.Sargos@bordeaux.unicancer.fr

15 Department of Urology, Sorbonne University, GRC 5 Predictive Onco-Uro, AP-HP, Urology, Pitie-Salpetriere Hospital, 75013 Paris, France; mroupret@gmail.com

16 IRSET (Institut de Recherche en Santé, Environnement et Travail), University of Rennes, Inserm, EHESP, 35000 Rennes, France

* Correspondence: gasmianis16@gmail.com

\begin{abstract}
Deregulation of the PI3K-Akt-mTOR pathway plays a critical role in the development and progression of many cancers. In prostate cancer, evidence suggests that it is mainly driven by PTEN loss of function. For many years, the development of selective Akt inhibitors has been challenging. In recent phase II and III clinical trials, Ipatasertib and Capivasertib associated with androgen deprivation therapies showed promising outcomes in patients with metastatic castrationresistant prostate cancer and PTEN-loss. Ongoing trials are currently assessing several Akt inhibitors in prostate cancer with different combinations, at different stages of the disease.
\end{abstract}

Keywords: prostate cancer; Akt; PTEN; castration resistance; Ipatasertib; Capivasertib

\section{Introduction}

Akt protein, also known as protein kinase B (PKB), is at the crossroads of several signalling pathways. This protein plays a critical role in regulating diverse cellular functions including cell metabolism, proliferation, apoptosis suppression and angiogenesis. Alterations in the Akt-dependent pathways are associated with cancer, diabetes, cardiovascular and neurological diseases [1]. The upregulation of Akt has been reported in a variety of human malignancies, including digestive, neurological, gynaecological, and urological 
cancers [2]. Akt promotes cell survival and proliferation through its effects on the cellular growth factors and inhibits apoptosis through the inactivation of pro-apoptotic proteins [3]. Given these properties, there is a growing interest in developing anti-cancer drugs targeting this pathway. We aimed to describe, in this review, the PI3K-Akt pathway and the use of Akt inhibitors in prostate cancer.

\section{PI3K-Akt-mTor Pathway Physiology and Drug Development}

Akt is a cytosolic serine/threonine kinase that has three isoforms (Akt 1, 2 and 3). Structurally, it comprises three domains: a carboxyl-terminal, a central and an amino-terminal fragment. Akt isoforms are similar in their catalytic domains but diverge in the regulatory domain. Akt1 and Akt2 are ubiquitous, whereas Akt3 is predominantly found in the kidney, brain and heart. Their functions are partially overlapping but are distinct in cancer cells [4].

Akt, together with phosphoinositide 3-kinase (PI3K), are key elements of the AKT signalling cascade, which is also known as the PI3K/Akt pathway. It promotes growth and survival in response to extracellular stimuli. This signalling cascade can be activated by cytokine receptors, integrins, receptor tyrosine kinases, B and T cell receptors, G-proteincoupled receptors, and other signals [5].

Once activated, PI3K phosphorylates PIP2 (phosphatidylinositol 4,5-bisphosphates) to PIP3 (phosphatidylinositol $(3,4,5)$-trisphosphates), a reaction that is negatively regulated by PTEN (phosphatase and tensin homolog chromosome 10). PIP3 then recruits Akt and allows its phosphorylation through pyruvate dehydrogenase kinase 1 (PDK1) and mammalian target of rapamycin complex 2 (mTORC2). Then, Akt phosphorylates different membrane, cytosolic and nucleic proteins involved in cell growth and survival, among other cellular effects (Figure 1). Mammalian target of rapamycin (mTOR) is a downstream member of the Akt pathway and a key regulator of cell growth and metabolism [6].

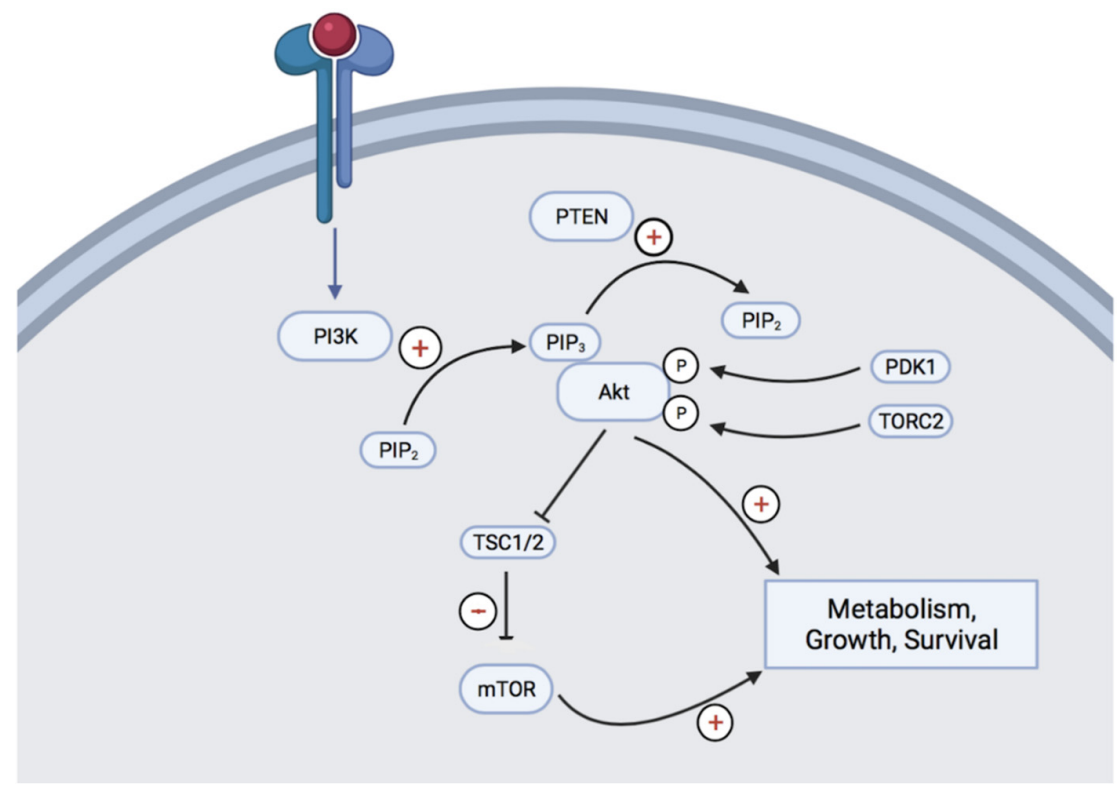

Figure 1. Overview of the PI3K-Akt-mTOR pathway.

PI3K: phosphoinositide 3-kinase, Akt: protein kinase B, PIP2: phosphatidylinositol 4,5-bisphosphates, PIP3: phosphatidylinositol (3,4,5)-trisphosphates, PTEN: phosphatase and tensin homolog chromosome 10, PDK1: pyruvate dehydrogenase kinase 1, mTORC2: mammalian target of rapamycin complex 2, TSC1/2: tuberous sclerosis proteins 1 and 2, mTOR: mammalian Target Of Rapamycin.

Thus, the PI3K/Akt pathway is one of the most commonly deregulated signalling pathways in human cancers, contributing to tumorigenesis and metastasis. Several of the proteins 
involved in the PI3K-Akt-mTOR signalling pathway can function, when overexpressed, as oncoproteins, while the ones involved in quenching this pathway act as tumour suppressors.

Its deregulation is commonly associated with tumour aggressiveness and resistance to chemotherapy or radiotherapy [7]. Therefore, targeting this pathway with drug inhibitors may result in a strong and efficient anticancer effect.

Initial attempts to inhibit this signalling pathway in prostate cancer-targeted mTOR protein. All clinical trials that evaluated mTor inhibitors: Rapamycin [8], Temsirolimus [9] and Everolimus [10] were unsuccessful, with no significant antineoplastic activity.

For years, efforts have been made to develop Akt inhibitors. The research focused predominantly on the development of two separate classes: allosteric inhibitors of the Akt PH-domain and ATP-competitive inhibitors of Akt. Despite all efforts, the clinical outcomes for both classes have been disappointing. Indeed, Akt belongs to the AGC kinases family, and one of the main issues hindering drug design efforts consists of achieving selectivity over structurally similar protein kinases. The existence of three isoforms, that diverge in their affinity for ligands, function, and tissue distribution, has also hampered the development of effective Akt inhibitors [11].

Another challenge is the frequent network branching and intense cross-talk with other signalling pathways that can reverse drugs mediated inhibition effects and restore paradoxical active signalling through a high number of mechanisms.

Ultimately, the toxicity of these molecules was significant and has long worked against their development [12].

\section{PI3K-Akt-mTor Pathway in Prostate Cancer}

Increasing evidence from in vitro and animal models studies demonstrates that the PI3KAkt-mTOR pathway plays a critical role in prostate cancer development and progression [13]. There is evidence that the deregulation of this pathway is associated with higher grade (Gleason 8-10), advanced stage (T3b-T4), and evolution to castration-resistant disease [14-17].

Several studies suggest that the Akt signalling cascade is upregulated in up to $50 \%$ of prostate cancers, through a variety of genetic alterations. Akt genetic aberrations increasing its activity have been detected in multiple malignancies but are rare events in prostate cancer $(\leq 0.9 \%)$, whereas high-level gene amplification of Akt isoforms is more common (up to $4.5 \%$ ) and positively correlates with the tumour aggressiveness [18]. In prostate cancer, the deregulation of the PI3K-Akt-mTOR pathway may be mainly driven by PTEN loss of function [19].

PTEN is a protein phosphatase that has been shown to negatively regulate this pathway by dephosphorylating PIP3 back to PIP2 (Figure 1). PTEN somatic mutations are described in many human cancers and represent the most common cause of activation of the Akt signalling pathway. Multiple mechanisms can impair PTEN activity, including homozygous deletions, somatic mutations, epigenetic or post-transcriptional modifications [20].

Its loss occurs in approximately $20 \%$ of primary prostate cancer and $50 \%$ of castrationresistant prostate tumours, depending on the study population [21].

Fluorescence in situ hybridisation (FISH) is a quantitative and highly specific method for the determination of gene copy numbers within interphase cells in tissue sections. It has long been used to detect genomic deletions of the PTEN locus. Since different mechanisms can lead to PTEN loss in prostate cancer, FISH may be underestimating the frequency of loss of PTEN [22]. Immunohistochemistry (IHC) is a less expensive and time-consuming alternative that determines the overall cellular PTEN protein expression and that could be used in routinely processed clinical pathology specimens [23]. Many protocols have been successfully validated and good concordance has been demonstrated between FISH detection of PTEN gene deletions and PTEN protein expression by IHC [23,24]. Overall, initial screening, in human prostate tissue, for PTEN loss by IHC followed by FISH analysis in ambiguous or indeterminate cases constitute the most time-effective and cost-effective protocol [25].

Pre-clinical and clinical data suggest that tumours with PTEN loss are more sensitive to AKT inhibition and support PTEN loss as a predictive factor of response to therapies 
targeting the Akt pathway [26]. A reciprocal relationship has been demonstrated between androgen receptor (AR) and Akt pathways in preclinical prostate cancer models with PTEN loss, such that inhibition of one leads to up-regulation of the other [21,27].

Key actors of the Akt pathway are directly involved in AR's expression and transcriptional activity [28]. It has been demonstrated that AR phosphorylation and activation by Akt occurs predominantly at low androgen concentrations, suggesting an important role of Akt in cell growth promotion in the castrate state [29]. Indeed, the activation of the PI3KAkt-mTOR pathway induced by PTEN loss and anti-AR treatments may promote prostate cancer cells proliferation and survival in androgen-reduced conditions. Conversely, in vitro studies have shown an AR-mediated activation of mTOR independently of PI3K-Akt stimulation in prostate cancer cells stimulated with Dihydrotestosterone (DHT) [30]. Recent discoveries indicate that the complex crosstalk between these two pathways promotes cancer progression and influences the sensitivity of prostate cancer cells to Akt inhibitors and androgen-deprivation therapies. Dual pathway inhibition may therefore result in a synergistic antitumor activity [31].

\section{Akt Inhibitors in Prostate Cancer}

Based on the elements outlined above and given the activation of the PI3K-Akt-mTOR pathway associated with a crosstalk with the AR pathway in metastatic Castration-Resistant Prostate Cancer (mCRPC), several clinical trials assessed the safety and efficacy of different Akt inhibitors combined with androgen deprivation therapies. We display herein the main outcomes of these studies.

Ipatasertib is an orally bioavailable inhibitor of all three Akt isoforms. It has been evaluated in a phase II randomised clinical trial, comparing Ipatasertib vs. placebo in Abiraterone-treated patients with MCRPC, with and without PTEN loss [32]. All patients had previously received Docetaxel and were randomised to three arms: Ipatasertib $200 \mathrm{mg}$, Ipatasertib $400 \mathrm{mg}$, or placebo, all combined with Abiraterone $1000 \mathrm{mg}$ orally, once daily. Ipatasertib $400 \mathrm{mg}$ showed a trend to increased radiological PFS (median 8.18 vs. 6.37 months; $\mathrm{HR}=0.75 ; p=0.17$ ) and increased OS (median 18.92 months vs. 15.64 months; $\mathrm{HR}=0.72 ; p=0.22$ ), compared to placebo. Patients with PTEN loss had a superior radiological PFS benefit versus those without. Adverse events (AEs) were consistent with those reported in the PI3K-Akt-mTOR pathway inhibitor class and included nausea, vomiting, diarrhoea, rash, asthenia, hyperglycemia and decreased appetite. Proportions of grade $\geq 3$ AEs were 50.6\%, 64.3\%, and 35.4\% in the Ipatasertib $200 \mathrm{mg}$, Ipatasertib $400 \mathrm{mg}$ and placebo groups, respectively. These AEs were dose dependent and did not impact treatment dose intensity. AEs that led to discontinuation of the treatment occurred in $7(8.0 \%)$ and $10(11.9 \%)$ patients in the Ipatasertib 200 and 400 mg cohorts, respectively; none occurred with placebo.

Results from IPATential150, the first phase III randomised double-blind trial, involving an AKT inhibitor in prostate cancer have been recently published [33]. This study compared Ipatasertib vs. Placebo, both combined with Abiraterone in MCRPC as a first line treatment. Patients were randomised 1:1 to receive Ipatasertib $400 \mathrm{mg}$ + Abiraterone $1000 \mathrm{mg}$, once daily + Prednisone $5 \mathrm{mg}$, twice daily or Placebo + Abiraterone + Prednisone. Investigator-assessed radiographic (r) PFS, according to RECIST version 1.1 or PCWG3 criteria, in patients with PTEN-loss tumours and the overall ITT population, were the coprimary endpoints. Compared to placebo, Ipatasertib showed a significantly improved rPFS and antitumor activity in patient with PTEN loss (median 18.5 vs. 16.5 months, $\mathrm{HR}=0.77 ; p=0.0335$ ).

Median rPFS, in the intention to treat population, was 19.2 months in the IpatasertibAbiraterone group and 16.6 months in the Placebo-Abiraterone group ( $\mathrm{HR}=0.84 ; p=0.0431$, statistical significance set at $\alpha=0.01$ ). Secondary endpoints of confirmed objective response, PSA response, and time to PSA progression all favoured the Ipatasertib-Abiraterone arm. Secondary endpoints of confirmed objective response, PSA response, and time to PSA progression all favoured the Ipatasertib-Abiraterone arm. 
In the primary analysis, tumour PTEN status was centrally assessed using a validated IHC assay. In secondary and exploratory analyses, PTEN status or PIK3CA/AKT1/PTEN alterations were detected using next-generation sequencing. rPFS was also significant in this population (median 19.1 vs. 14.2 months, $\mathrm{HR}=0.65 ; p=0.0206$ ). In the ITT population the median rPFS was not statistically significant (19.2 vs. 16.6 months, $\mathrm{HR}=0.84 ; p=0.0431$, $\alpha=0.01$ ). There was a $76 \%$ concordance between the two assays and, $91 \%$ of samples that had PTEN loss by next-generation sequencing were also classified as having PTEN loss by IHC.

Among patients receiving Ipatasertib, Abiraterone Acetate and Prednisone, skin rash and diarrhoea were the predominant severe toxicities. There were more grade 3-4 AEs in the Ipatasertib group compared to the placebo group. The most common grade 3-4 AEs in the Ipatasertib-Abiraterone group were rash (16\%), aminotransferase increase (16\%), hyperglycaemia $(14 \%)$ and diarrhoea $(10 \%)$. Treatment related deaths occurred in two $(<1 \%)$ patients in the Placebo-Abiraterone group (lower respiratory tract infection and acute myocardial infarction) and two $(<1 \%)$ patients in the Ipatasertib-Abiraterone group (chemical pneumonitis and hyperglycaemia).

Capivasertib is another highly selective pan-AKT inhibitor that has been evaluated in a phase I dose-escalation study in combination with Enzalutamide in patients with mCRPC [34]. The phase II dose identified for Capivasertib was $400 \mathrm{mg}$. The most common grade $\geq 3$ AEs were rash (20\%) and hyperglycemia (26.7\%). Three patients among 12 had a composite response that was defined as PSA decline $\geq 50 \%$, radiological response and/or circulating tumour cell conversion. Responses occurred in patients with PTEN loss or AKT activating mutations. ProCAID, a phase II placebo-controlled randomised trial, evaluated Capivasertib associated with Docetaxel and Prednisolone in metastatic mCRPC [35]. Patients received up to ten 21-day cycles of docetaxel $\left(75 \mathrm{mg} / \mathrm{m}^{2}\right.$ the first day) and prednisolone (5 mg twice daily, orally, from day 1 to day 21) and were randomly assigned to receive either Capivasertib $320 \mathrm{mg}$ (orally, twice daily), or placebo, until the progression of the disease. The primary endpoint was the composite progression-free survival (cPFS) that included PSA progression events. Added to the chemotherapy, Capivasertib did not extend cPFS (median 7.03 vs. 6.70 months; $\mathrm{HR}=0.92 ; p=0.32$ ) irrespective of PI3K-AKT-PTEN pathway activation status. However, there was an increased OS (secondary endpoint) with Capivasertib vs. placebo (median 31.15 vs. 20.27 months; $\mathrm{HR}=0.54 ; p=0.01$ ). The most common adverse events of any grade related to Capivasertib were nausea, diarrhoea, rash, and fatigue (Table 1).

Table 1. IPATASERTIB (IPATential150) versus CAPIVASERTIB (ProCAID) in prostate cancer.

\begin{tabular}{ccc}
\hline & IPATASERTIB & CAPIVASERTIB \\
\hline Clinical trial & IPATential & ProCAID \\
\hline Phase & III & II \\
\hline Number of patients enrolled & 1101 & cPFS \\
\hline Primary endpoint & rPFS & mCRPC \\
\hline Stage of the disease & mCRPC & Docetaxel + Prednisolone \\
\hline Association to AKTi & Abiraterone + Prednisolone & Placebo \\
\hline Control & Placebo & $0.92(80 \%$ CI, $0.73-1.16) ; p=0.32$ \\
\hline Primary outcome's HR & $0.77(95 \%$ CI, $0.61-0.98) ; p=0.034$ & $62 \%$ \\
\hline Grade $\geq 3$ adverse events & $70 \%$ & $23 \%$
\end{tabular}

rPFS: radiological progression-free survival; cPFS: composite radiological progression-free survival; AKTi: AKT inhibitor; mCRPC: metastatic castration resistant prostate cancer, HR: Hazard Ratio; AEs: adverse events.

\section{Ongoing Trials}

Several ongoing trials assess several Akt inhibitors in prostate cancer with different combinations, at different stages. These trials are summarised in Table 2 [36]. 
Table 2. Ongoing trials in Prostate Cancer using Akt inhibitors.

\begin{tabular}{|c|c|c|c|c|c|c|c|c|}
\hline Drug & Phase & NCT Number & Conditions & Investigator & Regimen & Status & Title of the Study & Primary Outcome \\
\hline Capivasertib & III & NCT04493853 & $\begin{array}{l}\text { De novo metastatic } \\
\text { hormone-sensitive } \\
\text { prostate cancer with } \\
\text { PTEN deficiency }\end{array}$ & AstraZeneca & $\begin{array}{c}\text { Capivasertib + } \\
\text { Abiraterone }\end{array}$ & Recruiting & $\begin{array}{l}\text { A double-blind, randomised, } \\
\text { placebo-controlled study } \\
\text { assessing the efficacy and safety } \\
\text { of Capivasertib + Abiraterone } \\
\text { versus placebo+abiraterone as a } \\
\text { treatment for patients with } \\
\text { denovo metastatic } \\
\text { hormone-sensitive prostate } \\
\text { cancer characterised by PTEN } \\
\text { deficiency. }\end{array}$ & $\begin{array}{l}\text { Radiographic } \\
\text { progression-free } \\
\text { survival (rPFS). }\end{array}$ \\
\hline $\begin{array}{l}\text { Capivasertib } \\
\text { (AZD5363) }\end{array}$ & I & NCT04087174 & $\begin{array}{c}\text { Metastatic } \\
\text { castration-resistant } \\
\text { prostate cancer }\end{array}$ & $\begin{array}{l}\text { AstraZeneca } \\
\text { Parexel }\end{array}$ & $\begin{array}{l}\text { Cabivasertibe + } \\
\text { Enzalutamide or } \\
\text { Abiraterone }\end{array}$ & Completed & $\begin{array}{l}\text { Open-label, multi-centre study to } \\
\text { assess the safety, tolerability, and } \\
\text { pharmacokinetics of Capivasertib } \\
\text { (AZD5363) in combination with } \\
\text { novel agents in patients with } \\
\text { metastatic castration resistant } \\
\text { prostate cancer. }\end{array}$ & $\begin{array}{l}\text { Number of patients } \\
\text { with dose-limiting } \\
\text { toxicity and number of } \\
\text { patients with adverse } \\
\text { events. }\end{array}$ \\
\hline MK2206 & I & NCT01480154 & $\begin{array}{l}\text { Solid neoplasm, } \\
\text { melanoma, prostate } \\
\text { and kidney cancers }\end{array}$ & $\begin{array}{l}\text { Jyoti Malhotra } \\
\text { (Rutgers Cancer } \\
\text { Institute of New } \\
\text { Jersey) }\end{array}$ & $\begin{array}{l}\text { Akt inhibitor } \\
\text { MK2206 + Hydroxy- } \\
\text { chloroquine }\end{array}$ & $\begin{array}{l}\text { Active, not } \\
\text { recruiting }\end{array}$ & $\begin{array}{l}\text { Akt inhibitor MK2206 and } \\
\text { hydroxychloroquine in treating } \\
\text { patients with Advanced solid } \\
\text { tumours, melanoma, prostate or } \\
\text { kidney cancer. }\end{array}$ & $\begin{array}{l}\text { To define the } \\
\text { maximum tolerated } \\
\text { dose of MK-2206 and } \\
\text { hydroxychloroquine } \\
\text { when used in } \\
\text { combination. }\end{array}$ \\
\hline $\begin{array}{l}\text { Ipatasertib } \\
\text { (GDC-0068) }\end{array}$ & $\mathrm{Ib} / \mathrm{II}$ & NCT01485861 & $\begin{array}{l}\text { Castration-resistant } \\
\text { prostate cancer } \\
\text { previously treated } \\
\text { with Docetaxel }\end{array}$ & Genentech, Inc. & $\begin{array}{c}\text { Ipatasertibe or } \\
\text { Apitolisilib }+ \\
\text { Abiraterone }\end{array}$ & $\begin{array}{l}\text { Active, not } \\
\text { recruiting }\end{array}$ & $\begin{array}{l}\text { Ipatasertib (GDC-0068) or } \\
\text { Apitolisib (GDC-0980) with } \\
\text { Abiraterone Acetate versus } \\
\text { Abiraterone Acetate in patients } \\
\text { with castration-resistant prostate } \\
\text { cancer previously treated with } \\
\text { Docetaxel-based chemotherapy. }\end{array}$ & $\begin{array}{l}\text { Recommended phase } \\
\text { II dose of Ipatasertib, } \\
\text { percentage of } \\
\text { radiographic } \\
\text { progression and } \\
\text { progression free } \\
\text { survival with or } \\
\text { without PTEN loss. }\end{array}$ \\
\hline
\end{tabular}


Table 2. Cont.

\begin{tabular}{|c|c|c|c|c|c|c|c|c|}
\hline Drug & Phase & NCT Number & Conditions & Investigator & Regimen & Status & Title of the Study & Primary Outcome \\
\hline Ipatasertib & $\mathrm{Ib}$ & NCT04404140 & $\begin{array}{l}\text { Metastatic } \\
\text { castration- } \\
\text { resistant prostate } \\
\text { cancer }\end{array}$ & $\begin{array}{l}\text { Hoffmann-La } \\
\text { Roche }\end{array}$ & $\begin{array}{l}\text { Ipatasertib + } \\
\text { Atezolizumab + } \\
\text { Docetaxel }\end{array}$ & Recruiting & $\begin{array}{l}\text { A multicentre study } \\
\text { evaluating the safety, efficacy } \\
\text { and pharmacokinetics of } \\
\text { Ipatasertib In combination } \\
\text { with Atezolizumab and } \\
\text { Docetaxel in metastatic } \\
\text { castration-resistant prostate } \\
\text { cancer. }\end{array}$ & $\begin{array}{l}\text { Percentage of } \\
\text { patients with } \\
\text { adverse events, } \\
\text { confirmed PSA } \\
\text { response, overall } \\
\text { response rate. }\end{array}$ \\
\hline Ipatasertib & I & NCT03673787 & $\begin{array}{c}\text { Solid tumour, } \\
\text { glioblastoma, } \\
\text { metastatic prostate } \\
\text { cancer }\end{array}$ & $\begin{array}{c}\text { Juanita Lopez } \\
\text { (National Health } \\
\text { Service, UK) }\end{array}$ & $\begin{array}{c}\text { Ipatasertib + } \\
\text { Atezolizumab }\end{array}$ & Recruiting & $\begin{array}{l}\text { Ipatasertib in combination } \\
\text { with Atezolizumab in } \\
\text { patients with advanced solid } \\
\text { tumours with PI3K pathway } \\
\text { hyperactivation. }\end{array}$ & $\begin{array}{l}\text { To determine the } \\
\text { maximum tolerated } \\
\text { dose in Phase I. } \\
\text { Number and type of } \\
\text { treatment-related } \\
\text { adverse events of } \\
\text { the two drugs } \\
\text { combination. }\end{array}$ \\
\hline Ipatasertib & $\mathrm{I} / \mathrm{II}$ & NCT04737109 & $\begin{array}{c}\text { Localised } \\
\text { high-risk prostate } \\
\text { cancer }\end{array}$ & $\begin{array}{l}\text { David } \\
\text { VanderWeele } \\
\text { (Northwestern } \\
\text { University) }\end{array}$ & $\begin{array}{c}\text { Ipatasertib + } \\
\text { Darolutamide }\end{array}$ & Recruiting & $\begin{array}{l}\text { Neoadjuvant androgen } \\
\text { deprivation, Darolutamide, } \\
\text { and Ipatasertib in men with } \\
\text { localised, high-risk prostate } \\
\text { cancer. }\end{array}$ & $\begin{array}{c}\text { Pathological } \\
\text { Complete Response } \\
\text { Rate }\end{array}$ \\
\hline
\end{tabular}


Phase I and II studies are evaluating Ipatasertib safety, tolerability, pharmacokinetics and efficacy in combination with Hydroxychloroquine, PARP inhibitors or immunotherapies in patients with metastatic castration-resistant prostate cancer.

Trials are also ongoing at earlier stages of the disease. A phase III double-blind randomised placebo-controlled study now compares Capivasertib vs. placebo in patients with de novo metastatic hormone-sensitive prostate cancer characterised by PTEN deficiency, treated with abiraterone plus prednisone.

\section{Conclusions}

PI3K-AKT-mTOR is an important signalling pathway of cellular metabolism. Its deregulation has been shown to play a critical role in many cancers, particularly through PTEN alterations. In prostate cancer, a crosstalk with the AR pathway has been demonstrated, which may participate in resistance to castration and escape from hormone therapy. Preliminary clinical studies investigated the combined blockade of these two pathways and have shown encouraging results in terms of radiologic PFS in $\mathrm{mCRPC}$, more markedly in patients with PTEN loss, with a tolerance that appeared to be acceptable. Several trials based on these initial findings are ongoing. Future challenges will be to identify markers that will allow a better selection of patients who can benefit the most from Akt inhibitors, possibly at earlier stages of the disease.

Author Contributions: Writing—original draft preparation, A.G., R.M., G.P.; writing—review and editing, A.G., G.R., C.D., E.B., J.-B.B., L.B., G.C., G.F. (Gaëlle Fiard), G.F. (Gaëlle Fromont), M.G., A.R., R.R.-P., P.S., M.R., G.P., R.M. All authors have read and agreed to the published version of the manuscript.

Funding: This research received no external funding.

Institutional Review Board Statement: Not applicable.

Informed Consent Statement: Not applicable.

Data Availability Statement: Not applicable.

Conflicts of Interest: The authors declare no conflict of interest.

\section{References}

1. Arcaro, A.; Guerreiro, A.S. The phosphoinositide 3-kinase pathway in human cancer: Genetic alterations and therapeutic implications. Curr. Genom. 2007, 8, 271-306. [CrossRef] [PubMed]

2. Carnero, A. The PKB/AKT pathway in cancer. Curr. Pharm. Des. 2010, 16, 34-44. [CrossRef] [PubMed]

3. Altomare, D.A.; Testa, J.R. Perturbations of the AKT signaling pathway in human cancer. Oncogene 2005, 24, 7455-7464. [CrossRef] [PubMed]

4. Song, G.; Ouyang, G.; Bao, S. The activation of Akt/PKB signaling pathway and cell survival. J. Cell. Mol. Med. 2005, 9, 59-71. [CrossRef] [PubMed]

5. Guo, H.; German, P.; Bai, S.; Barnes, S.; Guo, W.; Qi, X.; Lou, H.; Liang, J.; Jonasch, E.; Mills, G.B.; et al. The PI3K/AKT Pathway and Renal Cell Carcinoma. J. Genet. Genom. 2015, 42, 343-353. [CrossRef] [PubMed]

6. Georgescu, M.M. PTEN Tumor Suppressor Network in PI3K-Akt Pathway Control. Genes Cancer 2010, 1, 1170-1177. [CrossRef] [PubMed]

7. West, K.A.; Castillo, S.S.; Dennis, P.A. Activation of the PI3K/Akt pathway and chemotherapeutic resistance. Drug Resist. Updat 2002, 5, 234-248. [CrossRef]

8. Armstrong, A.J.; Netto, G.J.; Rudek, M.A.; Halabi, S.; Wood, D.P.; Creel, P.A.; Mundy, K.; Davis, S.L.; Wang, T.; Albadine, R.; et al A pharmacodynamic study of rapamycin in men with intermediate- to high-risk localized prostate cancer. Clin. Cancer Res. 2010, 16, 3057-3066. [CrossRef]

9. Kruczek, K.; Ratterman, M.; Tolzien, K.; Sulo, S.; Lestingi, T.M.; Nabhan, C. A phase II study evaluating the toxicity and efficacy of single-agent temsirolimus in chemotherapy-naïve castration-resistant prostate cancer. Br. J. Cancer 2013, 109, 1711-1716. [CrossRef]

10. George, D.J.; Halabi, S.; Healy, P.; Jonasch, D.; Anand, M.; Rasmussen, J.; Wood, S.Y.; Spritzer, C.; Madden, J.F.; Armstrong, A.J. Phase 2 clinical trial of TORC1 inhibition with everolimus in men with metastatic castration-resistant prostate cancer. Urol. Oncol. 2020, 38, 79.e15-79.e22. [CrossRef] 
11. Kumar, C.C.; Madison, V. AKT crystal structure and AKT-specific inhibitors. Oncogene 2005, 24, 7493-7501. [CrossRef]

12. Rodon, J.; Dienstmann, R.; Serra, V.; Tabernero, J. Development of PI3K inhibitors: Lessons learned from early clinical trials. Nat. Rev. Clin. Oncol. 2013, 10, 143-153. [CrossRef]

13. Liao, Y.; Grobholz, R.; Abel, U.; Trojan, L.; Michel, M.S.; Angel, P.; Mayer, D. Increase of AKT/PKB expression correlates with gleason pattern in human prostate cancer. Int. J. Cancer 2003, 107, 676-680. [CrossRef]

14. Bitting, R.L.; Armstrong, A.J. Targeting the PI3K/Akt/mTOR pathway in castration-resistant prostate cancer. Endocr. Relat. Cancer 2013, 20, R83-R99. [CrossRef]

15. Robinson, D.; Van Allen, E.M.; Wu, Y.M.; Schultz, N.; Lonigro, R.J.; Mosquera, J.M.; Montgomery, B.; Taplin, M.E.; Pritchard, C.C.; Attard, G.; et al. Integrative clinical genomics of advanced prostate cancer. Cell 2015, 161, 1215-1228. [CrossRef]

16. Li, L.; Ittmann, M.M.; Ayala, G.; Tsai, M.J.; Amato, R.J.; Wheeler, T.M.; Miles, B.J.; Kadmon, D.; Thompson, T.C. The emerging role of the PI3-K-Akt pathway in prostate cancer progression. Prostate Cancer Prostatic Dis. 2005, 8, 108-118. [CrossRef]

17. McMenamin, M.E.; Soung, P.; Perera, S.; Kaplan, I.; Loda, M.; Sellers, W.R. Loss of PTEN expression in paraffin-embedded primary prostate cancer correlates with high Gleason score and advanced stage. Cancer Res. 1999, 59, 4291-4296.

18. Shukla, S.; Maclennan, G.T.; Hartman, D.J.; Fu, P.; Resnick, M.I.; Gupta, S. Activation of PI3K-Akt signaling pathway promotes prostate cancer cell invasion. Int. J. Cancer 2007, 121, 1424-1432. [CrossRef] [PubMed]

19. Morgan, T.M.; Koreckij, T.D.; Corey, E. Targeted therapy for advanced prostate cancer: Inhibition of the PI3K/Akt/mTOR pathway. Curr. Cancer Drug Targets 2009, 9, 237-249. [CrossRef] [PubMed]

20. Milella, M.; Falcone, I.; Conciatori, F.; Cesta Incani, U.; Del Curatolo, A.; Inzerilli, N.; Nuzzo, C.M.; Vaccaro, V.; Vari, S.; Cognetti, F.; et al. PTEN: Multiple Functions in Human Malignant Tumors. Front. Oncol. 2015, 5, 24. [CrossRef] [PubMed]

21. Carver, B.S.; Chapinski, C.; Wongvipat, J.; Hieronymus, H.; Chen, Y.; Chandarlapaty, S.; Arora, V.K.; Le, C.; Koutcher, J.; Scher, H.; et al. Reciprocal feedback regulation of PI3K and androgen receptor signaling in PTEN-deficient prostate cancer. Cancer Cell 2011, 19, 575-586. [CrossRef]

22. Reid, A.H.; Attard, G.; Ambroisine, L.; Fisher, G.; Kovacs, G.; Brewer, D.; Clark, J.; Flohr, P.; Edwards, S.; Berney, D.M.; et al. Molecular characterisation of ERG, ETV1 and PTEN gene loci identifies patients at low and high risk of death from prostate cancer. Br. J. Cancer 2010, 102, 678-684. [CrossRef]

23. Lotan, T.L.; Gurel, B.; Sutcliffe, S.; Esopi, D.; Liu, W.; Xu, J.; Hicks, J.L.; Park, B.H.; Humphreys, E.; Partin, A.W.; et al. PTEN protein loss by immunostaining: Analytic validation and prognostic indicator for a high risk surgical cohort of prostate cancer patients. Clin. Cancer Res. 2011, 17, 6563-6573. [CrossRef]

24. Sangale, Z.; Prass, C.; Carlson, A.; Tikishvili, E.; Degrado, J.; Lanchbury, J.; Stone, S. A robust immunohistochemical assay for detecting PTEN expression in human tumors. Appl. Immunohistochem. Mol. Morphol. 2011, 19, 173-183. [CrossRef]

25. Lotan, T.L.; Wei, W.; Ludkovski, O.; Morais, C.L.; Guedes, L.B.; Jamaspishvili, T.; Lopez, K.; Hawley, S.T.; Feng, Z.; Fazli, L.; et al. Analytic validation of a clinical-grade PTEN immunohistochemistry assay in prostate cancer by comparison with PTEN FISH. Mod. Pathol. 2016, 29, 904-914. [CrossRef]

26. Josephs, D.H.; Sarker, D. Pharmacodynamic Biomarker Development for PI3K Pathway Therapeutics. Transl. Oncogenom. 2016, 7 (Suppl. 1), 33-49. [CrossRef] [PubMed]

27. Mulholland, D.J.; Tran, L.M.; Li, Y.; Cai, H.; Morim, A.; Wang, S.; Plaisier, S.; Garraway, I.P.; Huang, J.; Graeber, T.G.; et al. Cell autonomous role of PTEN in regulating castration-resistant prostate cancer growth. Cancer Cell 2011, 19, 792-804. [CrossRef] [PubMed]

28. Yang, L.; Xie, S.; Jamaluddin, S.; Altuwaijri, S.; Ni, J.; Kim, E.; Chen, Y.-T.; Hu, Y.-C.; Wang, L.; Chuang, K.-H.; et al. Induction of androgen receptor expression by phosphatidylinositol 3-kinase/Akt downstream substrate, FOXO3a, and their roles in apoptosis of LNCaP prostate cancer cells. J. Biol. Chem. 2005, 280, 33558-33565. [CrossRef] [PubMed]

29. Manin, M.; Baron, S.; Goossens, K.; Beaudoin, C.; Jean, C.; Veyssiere, G.; Verhoeven, G.; Morel, L. Androgen receptor expression is regulated by the phosphoinositide 3-kinase/Akt pathway in normal and tumoral epithelial cells. Biochem. J. 2002, 366, 729-736. [CrossRef] [PubMed]

30. Xu, Y.; Chen, S.Y.; Ross, K.N.; Balk, S.P. Androgens induce prostate cancer cell proliferation through mammalian target of rapamycin activation and post-transcriptional increases in cyclin D proteins. Cancer Res. 2006, 66, 7783-7792. [CrossRef]

31. Lee, S.H.; Johnson, D.; Luong, R.; Sun, Z. Crosstalking between androgen and PI3K/AKT signaling pathways in prostate cancer cells. J. Biol. Chem. 2015, 290, 2759-2768. [CrossRef] [PubMed]

32. De Bono, J.S.; De Giorgi, U.; Rodrigues, D.N.; Massard, C.; Bracarda, S.; Font, A.; Arija, J.A.A.; Shih, K.C.; Radavoi, G.D.; Xu, N.; et al. Randomized Phase II Study Evaluating Akt Blockade with Ipatasertib, in Combination with Abiraterone, in Patients with Metastatic Prostate Cancer with and without PTEN Loss. Clin. Cancer Res. 2019, 25, 928-936. [CrossRef] [PubMed]

33. Sweeney, C.; Bracarda, S.; Sternberg, C.N.; Chi, K.N.; Olmos, D.; Sandhu, S.; Massard, C.; Matsubara, N.; Alekseev, B.; Parnis, F.; et al. Ipatasertib plus abiraterone and prednisolone in metastatic castration-resistant prostate cancer (IPATential150): A multicentre, randomised, double-blind, phase 3 trial. Lancet 2021, 398, 131-142. [CrossRef]

34. Kolinsky, M.; Rescigno, P.; Bianchini, D.; Zafeiriou, Z.; Mehra, N.; Mateo, J.; Michalarea, V.; Riisnaes, R.; Crespo, M.; Figueiredo, I.; et al. A phase I dose-escalation study of enzalutamide in combination with the AKT inhibitor AZD5363 (capivasertib) in patients with metastatic castration-resistant prostate cancer. Ann. Oncol. 2020, 31, 619-625. [CrossRef] 
35. Crabb, S.J.; Griffiths, G.; Marwood, E.; Dunkley, D.; Downs, N.; Martin, K.; Light, M.; Northey, J.; Wilding, S.; Whitehead, A.; et al. Pan-AKT Inhibitor Capivasertib with Docetaxel and Prednisolone in Metastatic Castration-Resistant Prostate Cancer: A Randomized, Placebo-Controlled Phase II Trial (ProCAID). J. Clin. Oncol. 2021, 39, 190-201. [CrossRef] [PubMed]

36. Available online: https:/ / clinicaltrials.gov (accessed on 15 November 2021). 